\title{
ANALISIS FRAMING PEMBERITAAN SENGKETA PILPRES TAHUN 2019 PADA SURAT KABAR JAWA POS
}

\author{
Muhammad Lukman Ihsanuddin \\ UIN Walisongo Semarang \\ lukmanihsanuddin@gmail.com
}

\begin{abstract}
This research was conducted in order to find out the objectivity of the media in delivering news of the 2019 presidential election dispute in the Republic of Indonesia. The research method used is qualitative using Robert N. Entman's framing approach. Sources of data in this study are primary data, data obtained from the Java post coverage from the 18 June to 28 June 2019 edition, and secondary data in the form of writing about Java post and books relating to Robert N. Entman's framing analysis. The results of his research are 1) The reporting written by journalists uses two depictions of moral values, namely positive values and negative values. Positive values are often raised to describe the actions of the Constitutional Court, KPU and candidate pair 01 JokowiMa'ruf Amin, while negative values are often raised against the depictions of the candidate pair 02 Prabowo-Sandi. Almost all news texts written by journalists describe the weak position of candidate pair 02 due to the weakness of the arguments submitted and the evidence and witnesses provided cannot be accounted for, even it is reported that candidate pair 02 has also submitted witnesses who provided false statements. The second aspect is regarding the position of Jawa Pos in reporting disputes over the results of the 2019 presidential election. Journalists in Jawa Pos felt less balanced in reporting the conflict. This can be seen from the emphasis which is indirectly more favorable for the position of candidate pair Jokowi-Ma' ruf Amin compared with candidate pair 02 Prabowo-Sandi. Almost all news taken as objects of study in this study tend to prioritize Jokowi-Ma'ruf Amin and marginalize Prabowo-Sandi's position.Candidate 01Jokowi-Ma'ruf Amin is depicted as a disadvantaged party by submitting the dispute of the 2019 presidential election results to the constitutional line while pair 02 of Prabowo-Sandi is described as a guilty party and does not have a strong basis to prove his allegations regarding fraud committed by the paslon 01 Jokowi-Ma'ruf Amin. 2) the reporting of postal Javanese journalists in reporting the 2019 Presidential Election Dispute conflict, lacking balance in presenting information, tended to support the candidate pair 1 Jokowi-Ma' ruf Amin.
\end{abstract}

Keywords: Framing, 2019 Presidential Election Dispute, Newspaper, Jawa Pos 


\begin{abstract}
Abstrak
Penelitian ini dilakukan dalama rangka ingin mengetahui objektifitas media dalam menyampaikan berita sengketa pilpres tahun 2019 di Republik Indonesia. Dalam penelitian ini mengungakan metode kualitatif dengan menggunakan pendekatan framing Robert. N. Entman. Sumber data dalam penelitian ini adalah data primer, data yang didapatkan dari pemberitaan Jawa pos dari edisi 18 Juni sampai 28 Juni 2019,dan data sekunder berupatulisan mengenai Jawa pos serta buku-buku yang berkaitan dengan analisisframing Robert. N. Entman. Hasil penelitiannya yaitu 1) Pemberitaan yang ditulis wartawan menggunakan dua penggambaran nilai moral, yaitu nilai positif dan nilai negatif. Nilai positif sering dimunculkan terhadap penggambaran tindakan $\mathrm{MK}$, KPU dan paslon 01 Jokowi-Ma'ruf Amin, sedangkan nilai negatif sering dimunculkan terhadap penggambaran tindakan paslon 02 Prabowo-Sandi. Hampir seluruh teks berita yang wartawan tulis mengambarkan lemahnya posisi paslon 02 karena tidak kuatnya dalil-dalil yang diajukan serta bukti-bukti dan saksi yang diberikan tidak dapat dipertanggungjawabkan, bahkan diberitakan bahwa paslon 02 juga telah mengajukan saksi yang memberikan keterangan palsu. Aspek kedua adalah mengenai posisi Jawa Pos dalam memberitakan sengketa hasil pilpres 2019.Wartawan Jawa Pos dirasa kurang berimbang dalam memberitakan konflik tersebut. Hal ini dapat dilihat dari penekanan yang secara tidak langsung lebih menguntungkan posisi paslon 01 Jokowi-Ma'ruf Amin dibanding dengan paslon 02 Prabowo-Sandi. Hampir seluruh berita yang diambil sebagai objek kajian dalam penelitian ini cenderung mengutamakan pihak Jokowi-Ma' ruf Amin dan memarjinalkan posisi Prabowo-Sandi. Paslon 01 Jokowi-Ma'ruf Amin digambarkan sebagai pihak yang dirugikan dengan adanya pengajuan sengketa hasil pilpres 2019 ke jalur konstitusi sedangkan paslon 02 Prabowo-Sandi digambarkan sebagai pihak yang bersalah dan tidak memiliki dasar yang kuat untuk membuktikan tuduhannya mengenai kecurangan yang telah dilakukan oleh paslon 01 Jokowi-Ma'ruf Amin. 2) pemberitaan wartawan Jawa pos dalam memberitakan konflik Sengketa Pilpres Tahun 2019, kurang berimbang dalam menyuguhkan informasi, cenderung mendukung pada paslon 1 Jokowi-Ma'ruf Amin.
\end{abstract}

Kata Kunci: Framing, Sengketa Pilpres 2019, Surat Kabar, Jawa Pos

\section{A. PENDAHULUAN}

Tahun 2019 bangsa Indonesia kembali menjalani momentum penting perjalanan kehidupan berbangsa dan bernegara, yaitu dengan digelarnya pesta demokrasi untuk memilih kembali pasangan presiden dan wakil presiden masa periode 2019-2024. Pemilu diadakan dengan mengusung dua kubu pasangan calon presiden dan wakil presiden (Capres - Cawapres), yaitu pasangan Jokowi Widodo-Ma'ruf Amin (Jokowi-Ma'ruf Amin) dan Prabowo Subianto-Sandiaga Salahuddin Uno (Prabowo-Sandi).
Pemilu yang dilaksanakan bersamaan dengan Pemilihan Umum Legislatif (Pileg), DPRI, DPRD Provinsi maupun DPRD Kabupaten/Kota pada 17 April 2019 tersebut, menyisakan polemic tentang hasil pemilu antara pasangan Jokowi-Ma'ruf Amin dan Prabowo-Sandi. Hal tersebut dipicu oleh adanya perbedaan perhitungan hasil pemilu yang ditetapkan oleh KPU dengan hasil perhitungan pihak PrabowoSandi berdasarkan dokumen C1 yang dimiliki oleh kubu 02 tersebut.

Berdasarkan penetapan hasil pemilu yang dibacakan KPU RI, Jokowi-Ma'ruf 
pasangan nomor urut 01 meraih 85.607.362 suara (55,50 persen), dengan memimpin kemenangan di 21 provinsi dan daerah pemilihan di luar negeri, yaitu Bali, Bangka Belitung, Kalimantan Utara, Kalimantan Tengah, Gorontalo, Kalimantan Barat, Sulawesi Barat, DIY, Kalimantan Timur, Lampung, Sulawesi Utara, Sulawesi Tengah, Jawa Timur, NTT, Jawa Tengah, Kepulauan Riau, DKI Jakarta, Papua Barat, Sumatera Utara, Maluku, dan Papua. Sementara Prabowo-Sandi mendapat 68.650.239 suara (44,50 persen), dengan memimpin kemenangan di 13 daerah yakni Provinsi Bengkulu, Kalimantan Selatan, Maluku Utara, Jambi, Sumatera Selatan, Sulawesi Tenggara, Sumatera Barat, Banten, NTB, Aceh, Jawa Barat, Sulawesi Selatan, dan Riau. (Lihat hasil rekapitulasi pilpres KPU 2019)

Hasil di atas berbeda dengan hasil rekapitulasi perolehan suara yang dimiliki oleh pihak Prabowo-Sandi berdasarkan dokumen C1 yang dimiliki, yaitu PrabowoSandi mendapatkan suara sebanyak 68.650.239 (52 persen). Sementara JokowiMa'ruf memperoleh 63.573.169 (48 persen) dari jumlah total suara sah 132.223.408, sehingga pihak Prabowo-Sandi mengajukan gugatan sengketa Pilpres 2019 kepada MK (Mahkamah Konstitusi) dan meminta MK menyatakan hasil rekapitulasi perolehan suara berdasarkan dokumen C1 yang dimiliki sebagai hasil Pilpres 2019 yang sah. (Detik.com)

Gugatan tersebut akhirnya disidangkan dengan proses yang cukup panjang dan secara otomatis menyita perhatian public, tidak terkecuali dari sorotan media masa. Karena memang sudah menjadi peran media massadalam menyampaikan sebuah informasi maupun suatu kebijakan pemerintah di masyarakat. Tidak bisa dipungkiri media massa merupakan suatu alat dan metode komunikasi yang kian berkembang pesat seiring dengan tingkat perkembangan teknologi komunikasi. Jika dirinci secara detail, metode komunikasi dalam dunia moderen saat ini yang merupakan pengembangan darikomunikasi verbal dan non-verbal melalui banyak bidang, antara lain jurnalistik,hubungan masyarakat, periklanan, pameran/ eksposisi, propa-ganda, serta publikasi.

Realitanya sebagai metode komunikasi media massa tidak bisa serta merta diterima apa adanya sebagaimana yang dimuat di dalamnya. Setidaknya terdapat dua konsep dalam melihat realitas refleksi media, yaitu media berperan aktif dalam mengkontruksi pesan atau media bersifat pasif dalam mengkontruksi pesan. Hal ini berkaitan dengan pembingkaian realitas yang kemungkinan dibuat oleh suatu media massa.

Atas dasar adanya kemungkinan pembingkaian realitas serta ketertarikan penulis terhadap kasus sengketa hasil Pilpres 2019 yang kemudian disidangkan oleh MK, menjadi alasan penulis ingin mengetahui bagaimana suatu media dalam menyajikan berita mengenai hal tersebut. Dalam tulisan ini penulis mengambil beberapa berita yang dimuat oleh surat kabar Jawa Pos yang bersangkutan dengan sidang sengketa Pilpres 2019. Untuk mengetahui hal tersebut penelitian dapat dilakukan dengan menggunakan analisis framing. 
Analisis framing adalah salah satu metode analisis teks yang berada dalam kategori penelitian konstruksionis, dimana realitas kehidupan sosial bukanlah realitas yang natural, melainkan hasil dari konstruksi. Konsentrasi analisis pada paradigma konstruksionis adalah menemukan bagaimana peristiwa atau realitas tersebut dikonstruksi, dengan cara apa konstruksi itu dibentuk. (Eriyanto, 2002:43)

Dengan menggunakan analisis framing dapat diketahui bagaimana media menggambarkan sebuah peristiwa dengan memilih aspek tertentu dan mengabaikan aspek yang lain, serta bagaimana media menempatkan informasi dalam konteks yang khas sehingga salah satu isu mendapat porsi dan sorotan yang lebih banyak ketimbang isu lain. Praktiknya, hampir semua media akan menyeleksi isu yang ada, menonjolkan isu tertentu dengan mengabaikan isu yang lain, menonjolkan aspek tertentu dari isu tersebut sambil menyembunyikan dan bahkan membuang aspek yang lain. Verifikasi dan seleksi data, penyajian dalam bentuk berita, hingga penempatannya di sebuah rubrik tertentu. Di sini realitas sosial dimaknai dan dikonstruksikan dengan makna tertentu. Semua elemen tersebut tidak hanya bagian dari teknis jurnalistik, tetapi menandakan bagaimana peristiwa dimaknai dan ditampilkan (Eriyanto, 2002:3).

\section{B. METODE PENELITIAN}

Jenis penelitian yang digunakan dalam meneliti surat kabar Jawa Pos ini adalah penelitian kualitatif. Menurut Bogdan dan Taylor, "metode kualitatif" merupakan prosedur penelitian yang menghasilkan data deskriptif berupa kata-kata tertulis atau lisan dari subyek yang diamati. Sehingga berdasarkan pengertian tersebut penelitian yang dilakukan terhadap surat kabar Jawa Pos ini dapat dikatakan sebagai penelitian kualitatif, dikarenakan penelitian ini tidak menggunakan angka atau rumus dalam mengumpulkan data maupun memberikan penafsiran terhadap hasilnya, melainkan menggunakan data deskriptif berupa bahasa dan teks-teks tertulis.

Sedangkan pendekatan yang digunakan adalah pendekatan framing Robert. N. Entman. Framing menurut Entman secara konsisten menawarkan sebuah cara untuk mengungkap the power of a communication text, yaitu menunjukkan identitas para aktor yang berkompetisi untuk mendominasi teks (Sobur, 2001:165).

Data primer dalam penelitian ini didapatkan dari surat kabar Jawa Pos yang menyajikan pemberitaan Sidang MK Sengketa Pilpres 2019 edisi 18 sampai 28 Juni 2019. Sedangkan data sekunder dalam penelitian ini adalah buku-buku yang berkaitan dengan analisis framing dan analisis teks media lainnya. Buku tersebut diantaranya adalah Analisis Teks Media (Suatu Pengantar Untuk Analisis Wacana, Analisis Semiotika, dan Analisis Framing) karya Alex Sobur, dan Analisis Framing (Konstruksi, Ideologi, dan Politik Media) karya Eriyanto.

Teknik pengumpulan data yang dilakukan dalam penelitian ini adalah dokumentasi. Dokumentasi dalam penelitian ini adalah surat kabar Jawa Pos yang memuat berita tentang Sidang MK Sengketa Pilpres 2019 serta beberapa

ISSN : 2085-3521, E-ISSN : 2548-9054 
data lain yang berhubungan dengan surat kabar Jawa Pos yang mendukung dalam penelitian ini. Dengan demikian, dokumen hasil dokumentasi yang digunakan dalam penelitian ini merupakan sebuah dokumen independen yang sudah ada sebelum penyusunan penelitian (Moelong, 2001:217).

Penelitian ini menggunakan teknik analisis framing dari Robert. N. Entman. Menurut Robert N. Entman apa yang kita ketahui tentang realitas atau tentang dunia tergantung pada bagaimana kita membingkai dan menafsirkan realitas tersebut.

Entman melihat framing dalam dua dimensi besar, yaitu seleksi isu dan penekanan atau penonjolan aspek-aspek tertentu dari realitas atau isu. Dalam prakteknya framing dijalankan oleh media dengan menyeleksi isu tertentu dan mengabaikan isu yang lain. Penonjolan aspek dari isu tersebut menggunakan berbagai strategi wacana, misalnya isu ditempatkan pada halaman depan, pengulangan, pemakaian grafis untuk mendukung dan memperkuat penonjolan, dan pemakaian label tertentu (Eriyanto, 2002:186-187).

Framing pada dasarnya merujuk pada pemberitaan definisi, penjelasan, evaluasi, dan rekomendasi dalam suatu wacana untuk menekankan kerangka berpikir tertentu terhadap peristiwa yang diwacanakan. Untuk mengetahui bagaimana pembingkaian yang dilakukan media, terdapat sebuah perangkat framing yang dikemukakan Entman yang dapat menggambarkan bagaimana sebuah peristiwa dimaknai dan ditandakan oleh wartawan. Menurut Entman, framing dalam berita dilakukan dengan empat cara, yaitu:

Pertama, identifikasi masalah (problem identification), yaitu peristiwa dilihat sebagai apa, dan dengan nilai positif atau negative. Elemen pertama ini merupakan bingkai utama/master frame yang menekankan bagaimana peristiwa dimaknai secara berbeda oleh wartawan, maka realitas yang terbentuk akan berbeda.

Kedua, identifikasi penyebab masalah (causal interpretation), yaitu siapa yang dianggap penyebab masalah. Penyebab disini bisa berarti apa (what), tetapi bisa juga berarti siapa (who). Bagaimana peristiwa dipahami, tentu saja menentukan apa dan siapa yang dianggap sebagai sumber masalah. Oleh sebab itu, masalah yang dipahami secara berbeda, maka penyebab masalahnya akan dipahami secara berbeda pula. Dengan kata lain, pendefinisian sumber masalah ini menjelaskan siapa yang dianggap sebagai pelaku dan siapa yang menjadi korban dalam kasus tersebut. Elemen framing yang dipakai untuk membenarkan/memberi argumentasi pada pendefinisian masalah yang sudah dibuat. Setelah masalah didefinisikan dan penyebab masalah sudah ditentukan, dibutuhkan argumentasi yang kuat untuk mendukung gagasan tersebut. Gagasan yang dikutip berhubungan denga sesuatu yang familiar dan dikenal oleh khalayak.

Ketiga, evaluasi moral (moral evaluation), yaitu penilaian atas penyebab masalah. Keempat, saran penanggulangan masalah (treatment recommendation), yaitu menawarkan suatu cara penanganan masalah dan kadang kala memprediksikan hasilnya. Elemen keempat ini dipakai 
untuk menilai apa yang dikehendaki oleh wartawan. Penyelesaian itu tentu saja sangat tergantung pada bagaimana peristiwa itu dilihat dan siapa yang dipandang sebagai penyebab masalah (Sobur,2001:172).

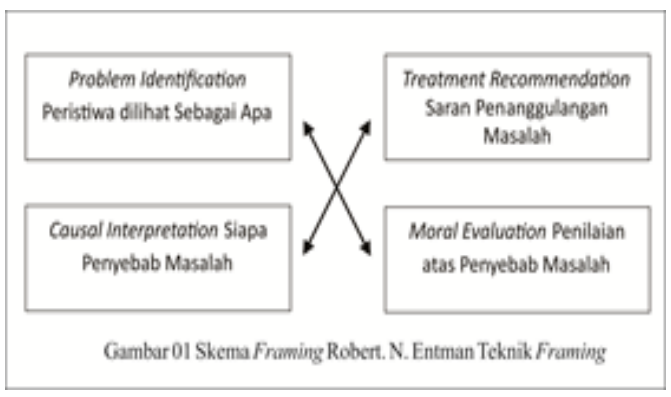

\section{HASIL DAN PEMBAHASAN}

Analisis Pemberitaan Sidang MK Sengketa Pilpres 2019 pada Surat Kabar Jawa Pos Edisi 18 Juni sampai 28 Juni 2019 Terdapat 6 berita yang diteliti, yaitu dengan judul berita sebagai berikut:

1. Datangkan 4 Truk Bukti (Edisi 18 Juni 2019)

Teks berita ini memberitakan tentang 4 truk bukti yang didatangkan oleh paslon nomor urut 02 Prabowo-Sandi untuk persiapan persidangan sengketa Pilpres 2019. Pasalnya masih ada 7 truk lagi yang akan dikirimkan ke MK yang sebelumnya belum masuk. Bukti-bukti apa saja yang disiapkan diantaranya adalah dokumendokumen C1, serta beberapa ratusan video yang dikirimkan oleh masyarakat sebagai bukti laporan kecurangan dari paslon nomor urut 01 Jokowi-Ma'ruf Amin. Teks berita tersebut juga menjelaskan bahwa MK membatasijumlah saksi dari masing-masing pihak dikarenakan waktu persidangan yang sangat terbatas.Pihak Jokowi-Ma'ruf Amin merasa tidak ada masalah dengan adanya system pembatasan saksi tersebut, sementara pihak Prabowo-Sandi merasa kurang dengan jumlah saksi yang dibatasi apabila semua dalil harus dibuktikan. Disisi lain wartawan juga menjelaskan bahwa penyebar hoaks system informasi penghitungan suara (situng) telah ditangkap oleh Mabes Polri. Sementara dari pihak KPU dan paslon 01 juga sudah menyiapkan jawaban dan bukti terkait dalil-dalil pemohon yang telah diajukan.

Terdapat beberapa definisi masalah (define problems) yang dikembangkan wartawan dalam berita tersebut. Pertama, mengenai pembatasan jumlah saksi dari semua pihak yang terkait yaitu hanya sebanyak 15 saksi dan 2 ahli, pembatasan jumlah saksi itu tidak dipermasalahkan dari pihak paslon 01 Jokowi-Ma'ruf Amin, akan tetapi sedikit mejadi masalah untuk pihak paslon 02 apabila semua dalil pemohon harus dibuktikan. Kedua, adanya perselisihan jumlah DPT yang diajukan oleh paslon 02 terhadap data KPU yang ada. Paslon 02 menganggap adanya DPT siluman sebanyak 17,5 juta-22 juta. Ketiga, penangkapan penyebar Hoaks situng oleh Mabes Polri.

Adanya masalah yang digambarkan oleh wartawan, maka kemudian akan muncul diagnose causes yaitu dimunculkannya penyebab dari munculnya masalah tersebut. Wartawan memunculkan tiga aktor yang lebih dominan dalam berita tersebut yaitu Kabag Humas dan Kerja Sama Dalam Negeri MK Fajar Laksono, Bambang Widjajanto sebagai kuasa hukum paslon 02 serta ketua dan komisioner KPU Arief Budiman dan Viryan Azis, sementara yang lain hanya sebagai pelengkap. 
Penggambaran masalah yang dilakukan oleh wartawan dalam teks berita tersebut menggunakan moral judment untuk melegitimasi ataupun mendelegitimasi suatu tindakan.Pertama, adanya pembatasan jumlah sakssi sebanyak 15 saksi dan 2 ahli oleh MK akibat terbatasnya waktu persidangan. Kedua, pihak paslon 02 dianggap mengada-ngada dengan pernyataan adanya DPT siluman sebanyak 17,5-22 juta karena adanya bukti jumlah perbandingan DPT yang dimiliki oleh pihak KPU dari tahun 2009. Ketiga, pihak KPU telah dirugikan akibat adanya penyebar hoaks system informasi penghitungan suara (situng).

Pada paragraf terakhir dari teks berita tersebut terdapat treatment recommendation. Secara tidak langsung wartawan menggambarkan bahwa pihak paslon 01 merasa sedikit dirugikan karena adanya perubahan tambahan permohonan dari pihak 02.

Jika dikaitkan dengan teori analisis Entman secara umum, secara garis besar framing dalam berita dapat dilihat dari dua aspek, yaitu seleksi isu dan penekanan aspek yang digunakan untuk menojolkan isu yang dipilh. Pertama, pada awal paragraph wartawan memang memberitakan tentang kedatangan truk-truk yang berisi barang bukti yang dimiliki paslon 02, akan tetapi setelahnya lebih focus pada klarifikasi pihak MK tentang adanya pembatasan saksi serta jawaban dan bukti yang telah disiapkan oleh pihak KPU dan paslon 01 untuk menjawab dalil-dalil yang telah diajukan oleh pihak 02 .

Kedua, aspek yang digunakan untuk memberikan penekanan pada isu yang telah dipilih oleh wartawan untuk ditulis. Aspek disini berkaitan dengan pemakaian kata, kalimat, gambar, serta citra tertentu dalam penulisan isu yang dipilih. Berita yang berjudul "Datangkan 4 Truk Bukti" ini memang diletakkan di halaman awal, akan tetapi hanya diberikan space kecil di kolom samping bagian tengah dan tidak terdapat gambar. Selain itu apa yang dibahas di dalamnya sebagian besar justru tidak mengenai bukti-bukti yang didatangkan oleh paslon 02, melainkan lebih fokus pada keputusan MK mengenai pembatasan jumlah saksi dan sejumlah klarifikasi dan bukti dari KPU dan paslon 01 untuk mengimbangi bukti dan tuduhan dari paslon 02 .

2. Sengketa Hasil Pilpres Periksa 14 Saksi dan 2 Ahli (Edisi 20 Juni 2019)

Teks berita ini memberitakan tentang lanjutan sidang sengketa hasil Pilpres 2019 pada tanggal 19 Juni, yang di dalamnya dilakukan pemeriksaan saksi-saksi dan ahli dari pihak Paslon 02. Dari 14 saksi dan 2 ahli, wartawan hanya memberitakan satu saksi dan satu ahli yaitu Listiani dan Said Didu.Listiani mengadukan Gubernur Jawa Tengah Ganjar Pranowo yang mendeklarasikan dukungan kepada paslon 01 (Jokowi-Ma'ruf Amin). Sementara Said Didu mempermasalahkan setatus Cawapres Ma'ruf Amin di anak perusahaan BUMN, dia menuturkan ada aturan dalam Undangundang BUMN yang selalu dicampur adukkan. Sebagai penutup, teks berita tersebut berisikan komentar dari ketua KPU Arief Budiman dan komisioner KPU Hasyim Asy'ari tentang saksi dari paslon 02 yang dirasa kurang pas dan kurang 
detail dalam menguraikan bukti-bukti pelanggaran yang dilakukan oleh paslon 01 , sehingga saksi-saksi yang dihadirkan oleh paslon 02 dinilai tidak memiliki kualitas sebagai saksi.

Definisi masalah (define problems) yang dikembangkan wartawan dalam berita tersebut adalah mengenai keterangan saksi dan ahli dari pihak paslon 02, diantaranya adalah Listiani dan Said Didu yang dirasa kurang kuat untuk membuktikan kesalahan yang dilakukan oleh paslon 01 Jokowi-Ma'ruf Amin. Pertama keterangan yang diberikan oleh Listiani tentang Ganjar Pranowo yang mendeklarasikan dukungan untuk paslon 01, ternyata hanya melalui video yang beredar di youtube dan tidak menyaksikan secara langsung. Selain Listiani, keterangan yang diberikan oleh Said Didu juga dianggap kurang jelas mengenai undang-undang yang berlaku di BUMN mengenai ketentuan status anggota BUMN.

\section{Diagnose causes (penyebab dari} munculnya masalah tersebut) yang dimunculkan oleh wartawan dalam teks tersebut adalah pihak saksi dan ahli Paslon 02 Listiani dan Said Didu serta pihak KPU yang diwakili oleh ketua KPU Arief Budiman dan komisioner KPU Hasyim Asy'ari. Wartawan menggambarkan pihak saksi dan ahli paslon 02 adalah penyebab masalah karena keterangan bukti tidak kuat dan dari beberapa pertanyaan yang diajukan kebanyakan jawabanya adalah tidak tahu. Sementara pihak KPU adalah pihak yang dirugikan dengan adanya keterangan yang kurang pas dan kurang detail tentang masalah yang diajukan oleh pihak paslon 02 .
Penggambaran masalah yang dilakukan oleh wartawan dalam teks berita tersebut menggunakan moral judment untuk melegitimasi ataupun mendelegitimasi suatu tindakan. Keterangan yang diberikan oleh Ketua KPU Arief Budiman dan komisioner KPU Hasyim Asy'ari mengenai kurang detail dan kurang kuatnya bukti yang disampaikan oleh saksi dan ahli paslon 02 merupakan nilai moral yang ingin disampaikan oleh wartawan atas ketidak kongkritan bukti-bukti kesalahan paslon 01 Jokowi-Ma'ruf Amin yang diajukan oleh paslon 02 Prabowo-Sandi .

Treatment recommendation kembali dmunculkan oleh wartawan dalam paragraph terakhir tesk berita ini.Secara tidak langsung wartawan menggambarkan bahwa para saksi dan ahli yang didatangkan oleh paslon 02, tidak layak disebut saksi. Sehingga kembali lagi ditegaskan bahwa tuduhan dari paslon 02 tidak adapat dibuktikan kebenarannya.

Seleksi isu dan penekanan aspek yang digunakan untuk menonjolkan isu yang dipilih adalah, pertama realitas yang dipilih wartawan dalam teks berita tersebut lebih menonjolkan tentang keterangan saksi dan ahli paslon 02 yang tidak kuat dan kurang pas saat menguraikan dan menjawab pertanyaan berkaitan dengan tuduhantuduhan yang diajukan oleh paslon 02 terhadap paslon 01.

Kedua, aspek yang digunakan untuk memberikan penekanan pada isu yang telah dipilih oleh wartawan untuk ditulis. Aspek disini berkaitan dengan pemakaian kata, kalimat, gambar, serta citra tertentu dalam penulisan isu yang dipilih. Di awal teks memang dijelaskan tentang keterangan

ISSN : 2085-3521, E-ISSN : 2548-9054 
saksi dan ahli paslon 02 mengenai bukti kesalahan yang dilakukan paslon 01 yaitu diantaranya adalah deklarasi dukungan dari Ganjar Pranowo dan Status Cawapres Ma'ruf Amin di BUMN, akan tetapi keterangan yang digambarkan oleh wartawan tidak menyeluruh dan terkesan memotong informasi, karena tidak diimbangi dengan hasil putusan dari bukti tersebut. Di sisi lain wartawan justru memberikan penekanan dan memunculkan respon dari pihak KPU Arief Budiman dan Hasyim Asy'ari yang terdapat pada kalimat di paragraf 12 dan paragraph 14,

“Ketua KPU Arief Budiman menjelaskan, saksi yang diajukan kemarin beberapa kali menyampaikan hal yang kurang pas. Sebab, dalam banyak keterangan, jawabannya adalah tidak tahu. Seharusnya, saksi bias menguraikan dengan detail sehingga kejadiannya bias diketahui semua pihak."

“Menurut dia (Hasyim Asy'ari), beberapa saksi yang diajukan kubu paslon 02 belum punya kualitas untuk memperkuat dalil yang diajukan pemohon."

Dari kedua keterangan di atas menegaskan bahwa apa yang dikatakan para saksi dan ahli paslon 02 kurang detail dan tidak bisa dibuktikan kebenarannya.

\section{Lebih Cepat Sehari dari Tenggat (Edisi} 25 Juni 2019)

Teks berita ini memberitakan tentang putusan MK yang akan dibacakan satu hari lebih awal dari deadline yang ditentukan, hal tersebut dijelaskan oleh Kabag Humas dan Kerjasama Dalam Negeri MK Fajar Laksono. Dikabarkan bahwa putusan jadwal tersebut berdasarkan pertimbangan internal para hakim konstitusi dalam forum rapat permusyawaratan hakim (RPH), dan semua pihak yang bersangkutan dengan perkara tersebut sudah dikirimi surat pemberitahuan. Dijelaskan dalam berita tersebut pihakpihak yang terkait diantaranya adalah KPU, Badan Pemenangan Nasional (BPN) Paslon Prabowo-Sandi, serta kubu Jokowi-Ma'ruf Amin tidak keberatan atas dimajukannya jadwal dari deadline yang telah ditentukan.Hal tersebut pun tidak termasuk pelanggaran, karena UU Pemilu hanya menentukan deadline bukan jadwal pembacaan putusan, yang terpenting tidak melebihi 14 hari kerja.Teks berita ditutup dengan pengerahan 13 ribu personel oleh polri dalam mengamankan sidang MK tersebut.

Definisi masalah (define problems) yang dikembangkan wartawan dalam berita tersebut adalah mengenai dimajukannya jadwal pengumuman keputusan sengketa hasil pemilu 2019 satu hari lebih cepat dari deadline yang ditentukan dalam UU pemilu. Kemudian wartawan menampilkan respon dari berbagai pihak yang terkait dengan perkara tersebut, baik itu dari pihak KPU, paslon 01, maupun paslon 02.Dari ketiganya tidak ada yang merasa keberatan dan berharap bahwa keputusan MK adalah keputusan terbaik dan dapat segera meredam ketegangan yang terjadi di masyarakat. Di sisi lain wartawan juga menampilkan sindiran keras dari koordinator juru bicara paslon 02 PrabowoSandi agar MK mengedepankan kejujuran dan keadilan.

Diagnose causes (penyebab dari munculnya masalah tersebut) yang dimunculkan oleh wartawan dalam teks 
tersebut menyangkut semua phak yang terlibat, yaitu MK, KPU, kubu paslon 01 dan kubu paslon 02. Dari keempat aktor yang dimunculkan, pihak paslon 02 digambarkan sedikit agresif dalam memberikan respon atas permasalahan yang dimunculkan oleh pihak MK, hal tersebut ditampilkan melalui komentar dari coordinator juru bicara paslon 02 Dahnil Anzar Simanjuntak agar MK tidak hanya sekedar menjadi "kalkulator pemilu".

Penggambaran masalah yang dilakukan oleh wartawan dalam teks berita tersebut menggunakan moral judment untuk melegitimasi ataupun mendelegitimasi suatu tindakan. Penjelasan mengenai UU pemilu yang hanya mengatur waktu deadline bukan jadwal diumumkannya keputusan merupakan digunakan sebagai poin untuk membenarkan putusan dari MK. Sementara komentar Dahil Anzar juru bicara dari Paslon 02 digunakan untuk menggambarkan respon dari kubu Prabowo-Sandi yang sedikit agresif dan berharap agar tuntutannnya diterima oleh MK.

Seleksi isu dan penekanan aspek yang digunakan untuk menonjolkan isu yang dipilih adalah, pertama realitas yang dipilih wartawan dalam teks berita tersebut secara keseluruhan adalah mengenai dimajukannya jadwal pengumuman hasil sengketa Pemilu 2019 dan persiapannya. Kemudian wartawan mencoba untuk memunculkan sedikit kritik dan sikap yang agresif yang ditunjukkan oleh pihak paslon 02 melalui komentar dari coordinator juru bicara paslon 02 Dahnil Anzar Simanjuntak.

Kedua, aspek yang digunakan untuk memberikan penekanan pada isu yang telah dipilih oleh wartawan untuk ditulis.Aspek disini berkaitan dengan pemakaian kata, kalimat, gambar, serta citra tertentu dalam penulisan isu yang dipilih. Wartawan menggunakan cuplikan komentar dari juru bicara paslon 02 Dahnil Anzar Simanjuntak, untuk memperlihatkan sikap yang agresif dalam menunggu keputusan yang akan dibacakan oleh MK. Seperti yang terdapat pada paragraph 14 .

“Tidak mereduksi MK sekadar menjadi mahkamah kalkulator".

4. Kapolri Larang Aksi Massa (Edisi 26 Juni 2019)

Berita dengan judul "Kapolri Larang Aksi Massa” yang rilis pada 26 Juni 2019 ini menyampaikan tentang larangan adanya aksi massa dalam bentuk apapun dari semua pihak demi keamanan dan kelancaran proses berjalannya sidang putusan MK. Puluhan ribu personel gabungan dari Polri dan TNI akan dikerahkan untuk melakukan pengamanan di berbagai titik rawan. Masyarakat dihimbau untuk menyaksikan sidang tersebut melalui siaran televise di rumah, karena proses sidang tersebut akan disiarkan secara langsung oleh beberapa stasiun televise.

Selain memberitakan mengenai hal yang telah disebutkan tadi, teks berita ini sedikit berbeda dengan beberapa berita sebelumnya yang penulis teliti, karena berita ini kembali memunculkan persaingan antara Badan Pemenangan Nasional (BPN) Prabowo-Sandi dan Tim Kampanye Nasional (TKN) Jokowi-Ma'ruf Amin dalam mempertahankan argument masingmasing. Pasalnya kubu paslon 02 optimis akan menang dari paslon 01, dan MK akan

ISSN : 2085-3521, E-ISSN : 2548-9054 
memutuskan bahwa paslon 01 JokowiMa'ruf Amin telah melakukan kecurangan. Sedangkan TKN Jokowi-Ma'ruf Amin menganggap dalil permohonan pemohon sangat lemah serta pihaknya telah membantah semua keterangan saksi dari paslon 02, bahkan terdapat saksi yang menyampaikan keterangan palsu sehingga paslon 01 juga optimis akan menang dan MK akan menolak seluruh permohonan pemohon.

Terdapat beberapa definisi masalah (define problems) yang dikembangkan wartawan dalam berita tersebut, selain mengenai larangan adanya aksi massa wartawan juga memunculkan ketegangan yang terjadi antara kubu paslon 01 Jokowi-Ma'ruf Amin dan kubu paslon 02 Prabowo-Sandi. Keduanya digambarkan sama-sama optimis akan memenangkan sengketa pemilu 2019. Di satu sisi paslon 02 yakin bahwa MK akan memutuskan bahwa Jokowi-Ma'ruf Amin melakukan kecurangan, sementara di sisi lain paslon 01 mengatakan bahwa dalil yang diajukan paslon 02 lemah dan tidak dapat dibuktikan kebenaranya, bahkan ada saksi yang memberikan keterangan palsu.

Adanya masalah yang digambarkan oleh wartawan, maka kemudian akan muncul diagnose causes yaitu dimunculkannya penyebab dari munculnya masalah tersebut. Wartawan kembali mengadu dua aktor dalam berita ini, yaitu pihak Prabowo-Sandi dan pihak Jokowi-Ma'ruf Amin.Badan Pemenangan Nasional Prabowo-Sandi diwakili oleh Andre Rosiade, sedangkan Tim Kampanye Nasional Jokowi-Ma'ruf Amin diwakili oleh Ade Irfan Pulungan.
Penggambaran masalah yang dilakukan oleh wartawan dimunculkan melalui kutipan-kutipan hasil wawancara dari kedua belah pihak (kubu PrabowoSandi dan kubu Jokowi-Ma'ruf Amin) sebagai cara untuk menggambarkan ketegangan yang terjadi antara keduanya dalam menunggu keputusan MK. Teks berita ini juga digunakan wartawan untuk membawa atmosfir ketegangan dan persaingan sengketa pilpres ke lapisan masyarakat melalui perang argument dari masing-masing pihak yang bersangkutan.

Jika dikaitkan dengan teori analisis Entman secara umum, secara garis besar framing dalam berita dapat dilihat dari dua aspek, yaitu seleksi isu dan penekanan aspek yang digunakan untuk menojolkan isu yang dipilh. Pertama, pada awal paragraph wartawan memberitakan tentang larangan adanya aksi massa apapun saat berlangsungnya pembacaan putusan MK, kemudian wartawan menggiring pembaca untuk turut masuk dalam suasana persaingan antara kubu paslon 01 dan kubu paslon 02 dalam memenankan hasil pilpres 2019.

Kedua, aspek yang digunakan untuk memberikan penekanan pada isu yang telah dipilih oleh wartawan untuk ditulis.Aspek disini berkaitan dengan pemakaian kata, kalimat, gambar, serta citra tertentu dalam penulisan isu yang dipilih.Penekanan diberikan oleh wartawan melalui teks kutipan-kutipan hasil wawancara dari pihak yang bersangkutan, baik itu kutipan langsung maupun tidak langsung. Wartawan juga mencoba menujukkan bahwa kubu paslon 01 menduduki posisi yang lebih kuat dengan memunculkan 
kutipan yang melemahkan posisi paslon 02 . Hal tersebut terlihat pada kalimat di bawah ini.

“Direktur Hukum Tim Kampanye Nasional (TKN) Jokowi-MA'ruf Amin Ade Irfan Pulungan mengungkapkan, pihaknya menganggap dalil permohonan pemohon sangat lemah.Kubu 02 mengajukan dua kali permohonan. "Keduanya sudah kami bantah," terang dia saat konfrensi pers di Media Center TKN, Jalan Cemara, Menteng."

"Pihaknya sudah membantah keterangan seluruh saksi paslon 02.Bahkan, ada yang menyampaikan keterangan palsu.Ahli yang mereka ajukan juga tidak punya kaitan dengan sengketa hasil pemilu."

5. Siap Terima Apapun Putusan MK (Edisi 27 Juni 2019)

Teks berita ini memberitakan tentang akan dibacakannya putusan sengketa pilpres oleh MK pada hari itu (27 Juni 2019). Saat ditanya tentang hasil putusan dan bagaimana teknik pembacaannya Fajar Laksono sebagai Kabaghumas dan Kerja Sama Dalam Negeri MK mengaku tidak tau, karena dia tidak terlibat sama sekali. Pada umumnya ketua MK membacakan pada awal putusan lalu kemudian dilanjutkan hakim-hakim yang lainnnya.

Teks berita tersebut juga menjelaskan bahwa pihak KPU, dan Prabowo-Sandi sudah siap dengan apapun yang akan menjadi keputusan dari MK. Walaupun mengaku menyerahkan sepenuhnya pada MK, akan tetapi sejak dari awal KPU sudah yakin bahwa dalil dan bukti yang diajukan oleh pihak Prabowo-Sandi tidak cukup kuat. Sementara disisi lain Prabowo-Sandi melalui juru bicaranya
Dahnil Anzar Simanjutak menjelaskan BPN telah melakukan upaya mencari legalitas dan legitimasi, yaitu dengan mengajukan kasus sengketa dan telah mendapatkan kepercayaan public bahwa telah terjadi kecurangan.

Definisi masalah (define problems) yang dikembangkan wartawan dalam berita tersebut hampir sama dengan beberapa berita sebelumnya, yaitu mengenai masih lemahnya dalil dan bukti yang diajukan oleh kubu Prabowo-Sandi mengenai kecurangan-kecurangan yang telah dilakukan oleh paslon Jokowi-Ma'ruf Amin dalam pemilu 2019.

Adanya masalah yang digambarkan oleh wartawan, maka kemudian akan muncul diagnose causes yaitu dimunculkannya penyebab dari munculnya masalah tersebut. Wartawan kembali mengangkat tiga aktor yaitu MK, KPU dan Kubu Prabowo-Sandi.

Penggambaran masalah yang dilakukan oleh wartawan dimunculkan melalui pernyataan dari KPU yang kembali melemahkan posisi Prabowo-Sandi.KPU kembali menyatakan bahwa dalil tuntutan yang diajukan ke MK masih sangat lemah, serta bukti-bukti yang diberikanpun tidak cukup kuat untuk membuktikan adanya kecurangan yang dilakukan oleh KPU dan kubu Jokowi-Ma'ruf Amin.

Jika dikaitkan dengan teori analisis Entman secara umum, secara garis besar framing dalam berita dapat dilihat dari dua aspek, yaitu seleksi isu dan penekanan aspek yang digunakan untuk menonjolkan isu yang dipilh. Pertama, wartawan kembali memilih dan menonjolkan tentang 
posisi kubu Prabowo-Sandi yang dianggap lemah dibandingkan dengan kubu JokowiMa'ruf Amin. Walaupun dalam kasus ini paslon 01 yang diajukan sebagai pihak yang telah melakukan kecurangan dalam proses pemilu 2019, akan tetapi justru pihak Prabowo-Sandi lah yang terlihat lemah dikarenakan dalil, bukti, serta saksi yang diajukan untuk membuktikan kecurangan Jokowi-Ma'ruf Amin dianggap masih lemah dan tidak bisa dipertanggung jawabkan.

Kedua, aspek yang digunakan untuk memberikan penekanan pada isu yang telah dipilih oleh wartawan untuk ditulis. Aspek disini berkaitan dengan pemakaian kata, kalimat, gambar, serta citra tertentu dalam penulisan isu yang dipilih. Penekanan diberikan oleh wartawan melalui teks kutipan-kutipan hasil wawancara dari pihak KPU.Seperti yang terdapat pada kalimat-kalimat di bawah ini.

"Menurut Hasyim, sampai dengan siding terakhir, KPU tetap meyakini bahwa apa yang didalilkan pemohon beserta alat buktinya tidak cukup kuat. Dia menjelaskan, ketika seseorang mendalilkan, dia harus membuktikan. “Ketika argumentasi dalilnya saja tidak meyakinkan dan alat bukti yang diajukan juga tidak meyakinkan, itu kan patah dengan sendirinya dalil-dalil pemohon 02," lanjutnya."

6. Tidak Ada Lagi 01 dan 02 (Edisi 28 Juni 2019)

Teks berita ini memberitakan tentang keputusan final yang diambil oleh MK terkait dengan sengketa hasil pilpres 2019. Dalam berita tersebut dituliskan MK menolak seluruh permohonan pemohon, karena dinilai tidak beralasan menurut hukum. Dalil-dalil pemohon tersebut diantaranya mengenai kecurangan yang terstruktur, sistematis dan massif (TSM), serta perbedaan data perolehan suara hasil rekapitulasi tingkat Nasional dengan data milik paslon 02. Menurut MK kubu 02 tidak bias menunjukkan upaya penyandingan dan koreksi saat proses rekapitulasi, artinya selain klaimnya tidak jelas, buktinya dinyatakan tidak kuat.

Wartawanmencantumkan respon dari kubu paslon 01 dan 02 dalam teks berita. Prabowo dalam pidatonya menerima semua hasil keputusan MK, dan berencana untuk mengumpulkan petinggi parpol koalisi serta bertemu dengan tim hukum untuk membicarakan langkah selanjutnya. Sementara Jokowi didampingi Ma'ruf Amin menyatakan pilpres 2019 telah selesai, masyarakat telah memutuskan pilihan politik kepada dirinya dan diperkuat dengan putusan MK. Jokowi juga menghimbau agar semua pihak menerima dengan besar hati, karena keputusan MK merupakan hasil final dan sidangnya pun dilakukan secara transparan.

Definisi masalah (define problems) yang dikembangkan wartawan dalam berita tersebut focus pada sidang pembacaan hasil putusan sengketa pilpres 2019 oleh MK yang merupakan putusan final dari proses konstitusi yang ditempuh. Dalam putusan itu MK menolak seluruh dalil permohonan pemohon paslon 02 Prabowo-Sandi.

Adanya masalah yang digambarkan oleh wartawan, maka kemudian akan muncul diagnose causes yaitu dimunculkannya penyebab dari munculnya masalah tersebut. Aktor yang diangkat oleh 
wartawan masih tetap sama dari beritaberita sebelumnya, yaitu MK, KPU, kubu paslon 01, dan kubu paslon 02. Disini wartawan terlihat memberikan ruang yang sama untuk semua pihak yang terlibat.

Penggambaran masalah yang dilakukan oleh wartawan dalam teks berita tersebutmenggunakanmoraljudmentuntuk melegitimasi ataupun mendelegitimasi suatu tindakan. Kemenangan JokowiMa'ruf Amin sebagai presiden dan wakil presiden periode 2019-2024 adalah poin utama yang ingin diangkat oleh wartawan dalam teks berita tersebut.

Jika dikaitkan dengan teori analisis Entman secara umum, secara garis besar framing dalam berita dapat dilihat dari dua aspek, yaitu seleksi isu dan penekanan aspek yang digunakan untuk menonjolkan isu yang dipilh. Pertama, wartawan memang terlihat memberikan ruang yang sama untuk semua pihak yang terlibat dalam kasus sengketa pilpres 2019. Diantaranya adalah MK, KPU, paslon 01 dan paslon 02. Akan tetapi secara tidak langsung wartawantetap mencoba menonjolkan salah satu pihak dan seedikit menggeser pihak lain dari perhatian publik. Berdasarkan analisa penulis, dalam teks berita ini wartawan kembali lagi mencoba untuk menonjolkan pihak paslon 01 dibandingkan paslon 02 .

Hal di atas dibuktikan dari aspek yang digunakan untuk memberikan penekanan pada isu yang telah dipilih oleh wartawan tersebut.Aspek disini berkaitan dengan pemakaian kata, kalimat, gambar, serta citra tertentu dalam penulisan isu yang dipilih. Penekanan terlihat diberikan oleh wartawan melalui beberapa teks diantaranya yang terdapat pada kalimat di bawah ini.
"Dengan demikian, tidak ada lagi yang bakal menghalangi pelantikan Joko WidodoMa'ruf Amin sebagai presiden-wakil presiden RI periode 2019-2024.

Selain itu pemilihan gambar pada halaman awal juga sangat mempengaruhi perhatian publik. Wartawan hanya mencantumkan gambar paslon 01 dan idak terdapat gambar dari paslon 02 .

\section{SIMPULAN}

Hasil analisis framing dengan menggunakan teori Robert. N. Entman pada pemberitaan terkait sengketa hasil pilpres 2019 capres dan cawapres di surat kabar Jawa Pos dapat dilihat dari dua aspek. Aspek pertama adalah mengenai framing yang dilakukan oleh wartawan Jawa Pos dalam teks-teks berita yang ditulis, dapat disimpulkan sebagai berikut: Wartawan dalam mendefinisikan dan melihat masalah terkait konflik sengketa hasil pilpres 2019 terkesan belum menyeluruh.

Dari beberapa teks berita yang penulis analisa wartawan memang lebih banyak memunculkan pihak paslon 02 dibandingkan paslon 01.Sehingga terkesan bahwa wartawan memberikan ruang lebih banyak terhadap pasangan Prabowo-Sandi dibanding Jokowi-Ma'ruf Amin.Akan tetapi setelah dianalisa kembali bahwa hampir seluruh berita yang dimuat oleh wartawan justru memperlihatkan kelemahan dari paslon 02 Prabowo-Sandi.Hal ini diperkuat wartawan dengan dimunculkanya responrespon dari MK dan KPU. Sehingga dapat tergambar sangat jelas bahwa paslon 02 Prabowo-Sandi merupakan tokoh yang dianggap sebagai penyebab masalah, sementara paslon 01 Jokowi-Ma'ruf Amin

ISSN : 2085-3521, E-ISSN : 2548-9054 
adalah sebagai korban yang telah dirugikan dengan adanya dalil-dalil yang diajukan oleh paslon 02 .

Pemberitaan yang ditulis wartawan menggunakan dua penggambaran nilai moral, yaitu nilai positif dan nilai negatif. Nilai positif sering dimunculkan terhadap penggambaran tindakan MK, KPU dan paslon 01 Jokpwi-Ma'ruf Amin, sedangkan nilai negatif sering diimunculkan terhadap penggambaran tindakan paslon 02 Prabowo-Sandi. Hampir seluruh teks berita yang wartawan tulis mengambarkan lemahnya posisi paslon 02 karena tidak kuatnya dalil-dalil yang diajukan serta bukti-bukti dan saksi yang diberikan tidak dapat dipertanggungjawabkan, bahkan diberitakan bahwa paslon 02 juga telah mengajukan saksi yang memberikan keterangan palsu.

Aspek kedua adalah mengenai posisi Jawa Pos dalam memberitakan sengketa hasil pilpres 2019.Wartawan Jawa Pos dirasa kurang berimbang dalam memberitakan konflik tersebut.Hal ini dapat dilihat dari penekanan yang secara tidak langsung lebih menguntungkan posisi paslon 01 Jokowi-Ma'ruf Amin dibanding dengan paslon 02 PrabowoSandi.Hampir seluruh berita yang diambil sebagai objek kajian dalam penelitian ini cenderung mengutamakan pihak JokowiMa'ruf Amindan memarjinalkan posisi Prabowo-Sandi.Paslon 01 Jokowi-Ma'ruf Amin digambarkan sebagai pihak yang dirugikan dengan adanya pengajuan sengketa hasil pilpres 2019 ke jalur konstitusi sedangkan paslon 02 PrabowoSandi digambarkan sebagai pihak yang bersalah dan tidak memiliki dasar yang kuat untuk membuktikan tuduhannya mengenai kecurangan yang telah dilakukan oleh paslon 01 Jokowi-Ma'ruf Amin.

\section{DAFTAR PUSTAKA}

Eriyanto, (2002). Analisis Framing (Konstruksi, Ideologi, dan Politik Media), Yogyakarta: LKIS.

Moleong, Lexy J, (2001). Metodologi Penelitian Kualitatif, Bandung: Remaja Rosdakarya.

Sobur, Alex, (2001). Analisis Teks Media, Suatu Pengantar Untuk Analisis Wacana, Analisis Semiotika, dan Analisis Framing, Bandung: Remaja Rosdakarya.

News, Detik, "Gugat Ke MK, PrabowoSandi Klaim Menang Pilpres 52 Persen", https://news.detik.com/ berita/d-4582464/gugat-ke-mkprabowo-sandi-klaim-menangpilpres-52-persen diakses $04 \mathrm{Juli}$, Pukul 19:17 WIB. 